\title{
A 3-Year Longitudinal Evaluation of Subpedicle Free Connective Tissue Graft for Gingival Recession Coverage
}

Yong-Moo Lee, * Jin Y. Kim, ${ }^{\dagger}$ Yang-Jo Seol, ${ }^{\ddagger}$ Young-Kyu Lee, ${ }^{\ddagger}$ Young Ku, ${ }^{*}$ In-Chul Rhyu, * Soo-Boo Han, * Sang-Mook Choi, ${ }^{*}$ and Chong-Pyoung Chung*

Background: The purpose of this study was to longitudinally evaluate, over a 3-year period, the reduction of gingival recession through use of a subepithelial free connective tissue graft placed under a coronally advanced partial-thickness pedicle flap.

Methods: Twenty-one buccal recession defects (mean $3.67 \mathrm{~mm}$; range 3 to $4.5 \mathrm{~mm}$; Miller Class I, II, and III) in 15 patients were treated using this technique. Amount of gingival recession (GR), clinical attachment loss (CAL), and width of keratinized gingiva (WKG) were followed for 3 years after surgery. The measurements were performed at presurgery, and $1,3,6,12,18,24$, and 36 months postsurgery.

Results: GR decreased from $3.67 \pm 0.58 \mathrm{~mm}$ at baseline to $0.33 \pm 0.43 \mathrm{~mm}$ at 36 months, representing a reduction of 3.33 $\mathrm{mm}$, corresponding to $91.28 \%$ mean root coverage. CAL was significantly decreased at 36 months from $5.26 \pm 0.77 \mathrm{~mm}$ to 2.14 $\pm 0.57 \mathrm{~mm}$. At 36 months, $3.12 \mathrm{~mm}$ of attachment gain was obtained. WKG significantly increased after 36 months $(1.95 \mathrm{~mm})$. GR, CAL, and WKG had the most positive outcomes at 12 months and were maintained at stable levels throughout the 36-month observation period.

Conclusions: These results indicate that the connective tissue graft with a partial thickness coronal advancement pedicle is a predictable method for root coverage and, provided that optimal maintenance care is provided, the clinical outcomes gained by this technique can be well maintained. $J$ Periodontol 2002;73:14121418.

\section{KEY WORDS}

Gingival recession/surgery; tooth root/surgery; gingival recession/therapy; follow-up studies; grafts, connective tissue; surgical flaps.

* Department of Periodontology and BK21HLS, College of Dentistry, Seoul National University, Seoul, Korea.

$\dagger$ Section of Periodontics, School of Dentistry, University of California-Los Angeles, Los Angeles, CA.

‡ Department of Periodontology, Samsung Medical Center, Sungkyunkwan University School of Medicine, Seoul, Korea.

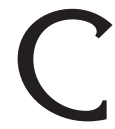
overing exposed root surfaces has become an integral part of surgical periodontal practice. Indications for root coverage procedures include esthetic concerns of patients, root sensitivity, root caries, and lack of keratinized gingiva. ${ }^{1}$ Many different surgical approaches including pedicle grafts, ${ }^{2-5}$ free gingival grafts, ${ }^{6-10}$ free connective tissue grafts, ${ }^{9-24}$ and guided tissue regeneration ${ }^{23-28}$ have been shown to result in effective root coverage. Each of these techniques has its advantages and disadvantages, indications and contraindications, and varying degrees of successful outcomes.

A major concern associated with free gingival grafts is the color discrepancy between the graft and surrounding tissue that has been described as a "keloid-like" appearance. ${ }^{12,29}$ Pedicle grafts including a laterally or coronally positioned flap can produce a more esthetic result. However, these procedures are indicated only when there is adequate donor tissue adjacent to the defect. ${ }^{29,30}$ More recently, guided tissue regeneration (GTR) using nonresorbable $24-26$ or bioabsorbable $23,27,28$ membranes has been introduced in the treatment of gingival recession. However, membrane exposure, a common occurrence, has been associated with significant reduction in root coverage. ${ }^{24}$ The utilization of GTR also incurs additional cost to the root coverage procedure.

The use of a connective tissue graft combined with a coronally positioned 
pedicle, ${ }^{12,15,16}$, laterally positioned pedicle, ${ }^{13}$ double pedicle, ${ }^{13,14,19-21,23}$ envelope flap, ${ }^{9,11,22}$ or tunneling technique ${ }^{17,18}$ has been shown to produce predictable and esthetic root coverage in multiple clinical studies. Many of these studies, however, lack long-term postoperative follow-up data.

The purpose of this study was to longitudinally evaluate, over a 3-year period, the reduction of gingival recession through a subepithelial free connective tissue graft placed under a coronally advanced partialthickness pedicle flap.

\section{MATERIALS AND METHODS}

\section{Study Population}

Fifteen healthy subjects, 22 to 44 (mean 30.5) years of age, were recruited for this study. The 9 male and 6 female patients had requested a surgical root coverage procedure for esthetic reasons; they presented a total of 21 recession sites.

The inclusion criteria were: 1) non-compromised systemic health; no contraindication for periodontal surgery; and no current smoking; 2) no periodontal surgery during the previous 24 months in involved sites; 3) presence of gingival recession $\geq 3 \mathrm{~mm}$; 4) presence of identifiable cemento-enamel junction (CEJ); and 5) presence of tooth vitality and lack of dental restorations in involved areas.

All subjects gave their informed consent for participating in this 3-year clinical study. Oral hygiene instructions were provided to eliminate habits which may have caused recession, such as harsh brushing, use of stiff bristles, etc. At least 2 sessions of prophylaxis were performed to remove microbial deposits from the root surfaces and to assess the patient's ability to maintain proper oral hygiene.

\section{Surgical Procedure}

Root coverage was surgically accomplished with a connective tissue graft combined with a partial-thickness pedicle, a modification of the Langer and Langer technique. ${ }^{12}$ All surgical procedures were performed by the same surgeon (YML).

Upon induction of local anesthesia, the exposed root surface was carefully planed with curets. A partialthickness flap was created with 2 vertical incisions placed at least one-half to one tooth wider mesiodistally than the area of gingival recession. Horizontal incisions were placed at the level of the CEJ. The coronal margin of the flap was initiated with a sulcular incision in order to preserve existing gingiva over the root surface. The interdental papillae were left intact. Flap reflection was carried out as partial thickness, leaving periosteum and connective tissue over the existing bone and/or root surface intact.

A connective tissue graft was then obtained from the palate. The donor area was restricted to the area between the maxillary first molar and maxillary cus- pid. Two parallel horizontal incisions, 1 to $1.5 \mathrm{~mm}$ apart, were made approximately $5 \mathrm{~mm}$ from the palatal gingival margins of maxillary teeth to the desired width. Vertical incisions were made, if needed, to provide greater access. The graft tissue of at least $1 \mathrm{~mm}$ in thickness was harvested and trimmed. The epithelial border of the graft was discarded.

The connective tissue was then sutured onto the recipient bed, using 5-0 gut sutures at the corner of the harvested graft to secure it to the recipient site. Overlying suspension sutures were utilized over the graft when more intimate contact between the graft and recipient bed was necessary. The partial-thickness recipient flap was positioned and sutured coronally to cover as much of the graft as possible, again using 5-0 gut sutures. No attempt was made to completely cover the graft in order to avoid unnecessary tension in the facial vestibule.

The recipient site was dressed with periodontal packing material, $\S$ and the patient was instructed on postsurgical management. The patients were recalled on the seventh postoperative day to remove the dressing and sutures. All patients were placed on $0.2 \%$ chlorhexidine digluconatell b.i.d for 4 weeks. Professional prophylaxis was carried out weekly for the first month and thereafter at 3-month intervals.

\section{Clinical Measurements}

Recordings of clinical data were made immediately before the surgical treatment and at $1,3,6,12,18$, 24 , and 36 months postsurgery. Prior to the study, 2 examiners (YJS and ICR) were calibrated to reduce intra- and interexaminer error (kappa $>0.75$ ) to establish reliability and consistency. Recording of data was carried out by the same examiner in the same patient in all clinical examinations.

For evaluation of oral hygiene and gingival health, the plaque index $(\mathrm{PI})^{31}$ and gingival index $(\mathrm{GI})^{32}$ were employed. Probing measurements were performed using a standard periodontal probe with $1 \mathrm{~mm}$ incremental markings and measured to the nearest $0.5 \mathrm{~mm}$. Gingival recession (GR) was measured between the most apical point of the facial CEJ to the most apical point of the facial gingival margin. Clinical attachment level (CAL) was measured between the CEJ and base of the sulcus; the width of keratinized gingiva (WKG) was measured from the most apical point of the gingival margin to the mucogingival junction after staining alveolar mucosa with an aqueous solution of $10 \%$ potassium iodide and 5\% iodine. All measurements were made at the experimental sites.

\section{Statistical Analysis}

Descriptive statistics were expressed as mean \pm standard deviation (SD). Percent root coverage (\%) was

$\S$ Coe-Pak, Coe Lab., Chicago, IL.

॥ Hexamedine, Bukwang Pharmaceutical Co., Seoul, Korea. 
calculated as $\left(G_{\text {presurgery }}-G_{36 \text {-month }}\right) / G_{\text {presurgery }}$. The 1-month postoperative appointment was selected as the creeping attachment starting point. ${ }^{21}$ Creeping attachment from 1 month was calculated as $\mathrm{GR}_{1 \text {-month }}$ $\mathrm{GR}_{\text {each period. }}$ Longitudinal alterations were tested by repeated measures analysis of variance (GR, creeping attachment, CAL, and WKT) or Friedman's test (PI and GI). A probability of $P<0.05$ was accepted to reject the null hypothesis.

\section{RESULTS}

Table 1 shows the distributions and Miller classifications ${ }^{33}$ of the 21 recession sites. Nine canines, 3 incisors, and 9 premolars representing 13 Class I, 7 Class II, and 1 Class III sites were treated.

The clinical procedures and results of 2 representative cases are shown in Figures 1 and 2.

Optimum levels of oral hygiene were demonstrated by the patients throughout the observation period (Table 2). The mean PI ranged between 0.1 and 0.3 , and the mean GI between 0.3 and 0.5.

Table 3 shows the changes in the level of the gingivae during the observation period. Gingival recession decreased from $3.67 \pm 0.58 \mathrm{~mm}$ at baseline to $0.33 \pm 0.43 \mathrm{~mm}$ at 36 months, representing a reduction of $3.33 \mathrm{~mm}$. This corresponds to mean root coverage of $91.28 \pm 11.47 \%$. At the final postoperative measurement (36 months), 11 of 21 sites (52.38\%) exhibited complete root coverage $(100 \%)$. The mean GR was reduced to $0.88 \mathrm{~mm}$ at 1 -month postoperative, which further decreased to $0.29 \mathrm{~mm}$ at 12 months. After 12 months, GR remained stable. At 3, $6,12,18$, and 36 months, the mean values of GR were significantly lower than at 1 month. Two out of 21 sites showed complete coverage at 1 month after surgery; in 9 sites at 6 months; 12 sites at 12 months; and 11 sites at 36 months.

The phenomenon of "creeping attachment" is believed to be responsible for this later change in gingival level. When the starting point of creeping attachment is con-

\section{Table I.}

\section{Distribution of 21 Recession Sites}

\begin{tabular}{lcccccc}
\hline & \multicolumn{3}{c}{ Maxilla } & \multicolumn{3}{c}{ Mandible } \\
\cline { 2 - 7 } Tooth & \multicolumn{3}{c}{ Miller Class } & \multicolumn{3}{c}{ Miller Class } \\
\hline Incisors & I & $\|$ & III & I & II & III \\
Canines & 0 & 0 & 0 & 0 & 2 & 1 \\
Premolars & 5 & 2 & 0 & 2 & 0 & 0 \\
Total & 3 & 2 & 0 & 3 & 1 & 0 \\
\hline
\end{tabular}

sidered as 1 month after surgery (Table 3 ), the maximum amount of creeping attachment $(0.60 \mathrm{~mm})$ is observed at 12 months; $0.55 \mathrm{~mm}$ of mean creeping attachment was observed in 16 of 21 sites (76.19\%) 36 months after surgery. There were no statistically significant differences between the amounts of creeping attachment seen at any time in the interval of 6 to 36 months postoperatively. Figure $2 \mathrm{C}$ clearly shows the occurrence of coronal migration of the gingival margin after grafting.

Clinical attachment gain was observed, as represented by significant decrease in CAL (Table 4) from baseline $(5.26 \pm 0.77 \mathrm{~mm})$ to 36 months $(2.14 \pm 0.57 \mathrm{~mm})$. At 1 -month postsurgery, CAL gain was $2.83 \pm 0.73 \mathrm{~mm}$. The pattern was similar to GR; continuous attachment gain was observed from 1 to 12 months postoperatively, after which CAL remained steady throughout the 3-year observation period (3.12 mm of attachment gain).

Mean width of keratinized gingiva (Table 5) increased at 36 months by $1.95 \mathrm{~mm}$. WKG increased from $0.88 \pm$ $0.72 \mathrm{~mm}$ at baseline to $2.81 \pm 0.49 \mathrm{~mm}$ at 1 month, after which it remained stable.

\section{DISCUSSION}

The results of this study confirm the predictability of the connective tissue graft placed under a coronally advanced partial-thickness pedicle as an effective and efficient method of obtaining esthetic root coverage.

The mean root coverage from baseline to final 3year postoperative results was $91.28 \%$ for this group of 21 recession sites in 15 patients. Complete (100\%) root coverage was obtained in 11 sites $(52.38 \%)$. The mean gain in CAL results from this study compare well with those of other authors employing different techniques. Raetzke $^{11}$ obtained $100 \%$ root coverage in $41.7 \%$ of cases and $80 \%$ mean root coverage at 8 months postsurgery utilizing the "envelope" technique. Jahnke et al. ${ }^{9}$ reported $80 \%$ mean root coverage at 6 months using connective tissue grafts. Müller et al. ${ }^{22}$ obtained $73 \%$ mean root coverage at 12 months using the envelope technique. Nelson ${ }^{13}$ obtained $100 \%$ root coverage in $62 \%$ of cases and $91 \%$ mean root coverage using the bilaminar technique at 6 to 42 months. Borghetti and Louise ${ }^{14}$ reported $70.9 \%$ mean root coverage using the double pedicle and full-thickness flap technique at 12 months. Harris ${ }^{19-21,23}$ obtained relatively higher root coverage rates than did others, reporting $97.4 \%$ at 12 weeks, ${ }^{19} 97.7 \%$ at a mean of 23 weeks, ${ }^{20}$ and $97.1 \%$ at 26 weeks $^{23}$ using a partial-thickness double pedicle graft. Except for the Nelson study, ${ }^{13}$ most studies reported, at most, 1 -year results. Paolantonio et al. ${ }^{10}$ reported results of a 5-year clinical study as $85.23 \%$ root coverage and $2.81 \mathrm{~mm}$ increase in keratinized gingiva, comparable to the results of the current study.

GR, CAL, and WKG had the most positive outcomes at 12 months. GR and CAL were significantly decreased 

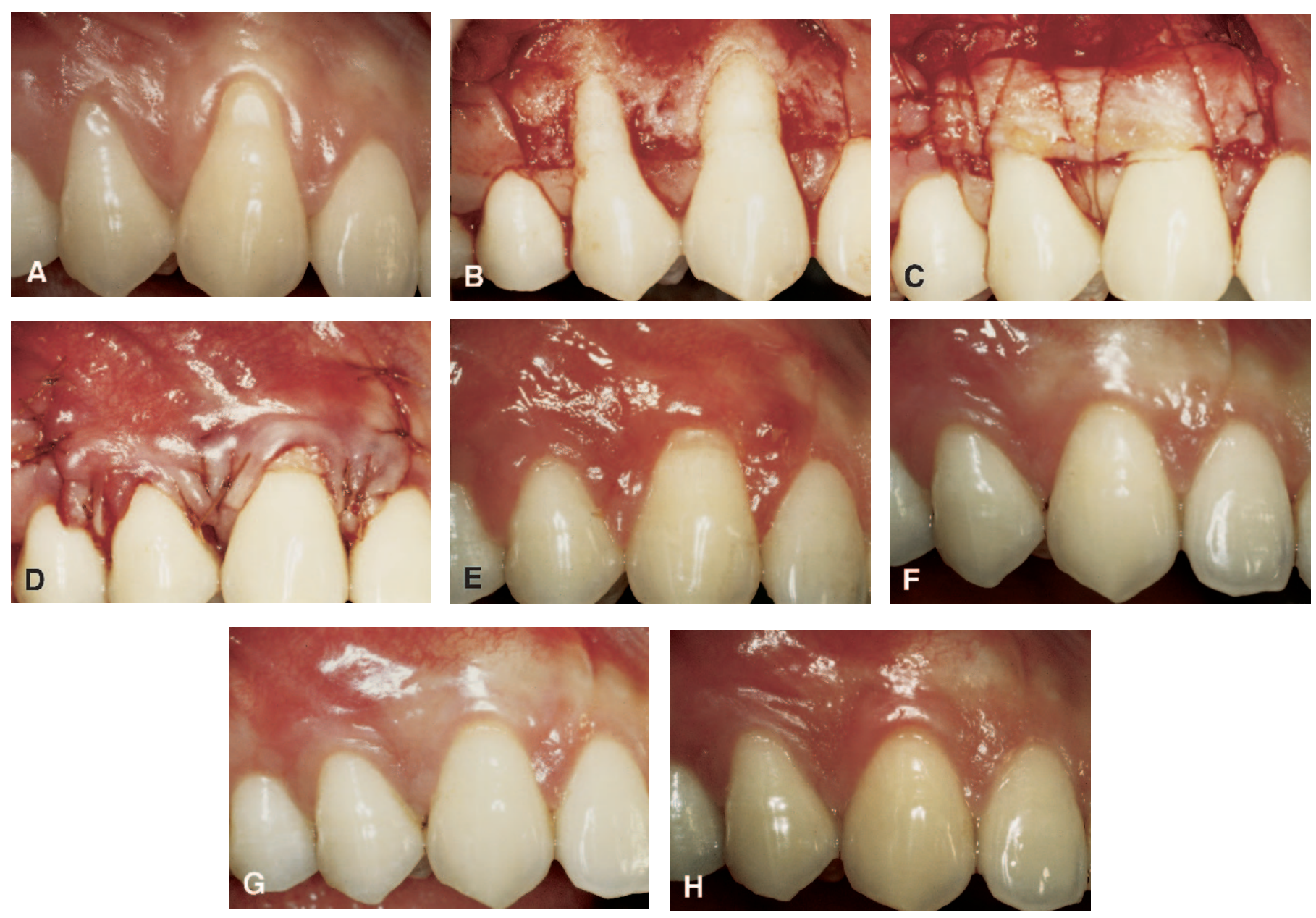

Figure I.

A. Preoperative recessions, upper right canine and first premolar. B. Reflection of partial-thickness pedicle flap. $\boldsymbol{C}$. Connective tissue graft sutured into recipient site. D. Pedicle flap sutured over connective tissue graft and denuded root surfaces. E. Postoperative at I month; $\boldsymbol{F} .6$ months; G. 12 months; and $\boldsymbol{H} .36$ months.
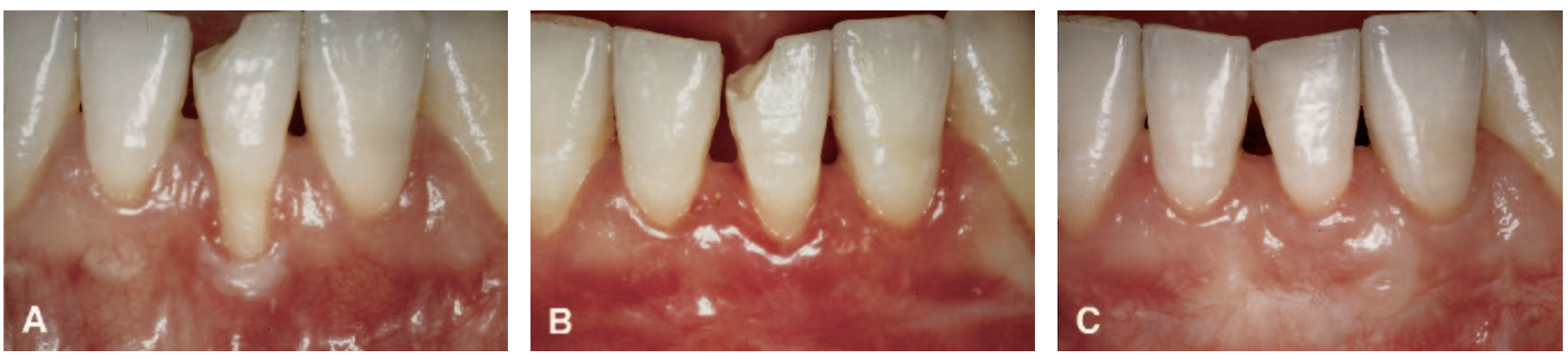

Figure 2.

A. Preoperative recession, lower left central incisor. B. Recession at creeping attachment starting point ( I-month postoperative). C. Postoperative 36 months: coronal migration of the gingival margin is evident at the lower left central incisor. Fractured incisal edge seen in A and B was restored with resin at 6 weeks postsurgery. 
Table 2.

Plaque (PI) and Gingival Index (GI) Scores Before and After Surgery

\begin{tabular}{ccccccccc}
\hline & & \multicolumn{7}{c}{ Month } \\
\cline { 3 - 9 } & Baseline & 1 & 3 & 6 & 12 & 18 & 24 & 36 \\
\hline PI (0-3) & $0.3 \pm 0.3$ & $0.2 \pm 0.3$ & $0.2 \pm 0.3$ & $0.1 \pm 0.2$ & $0.1 \pm 0.3$ & $0.2 \pm 0.3$ & $0.2 \pm 0.4$ & $0.3 \pm 0.3$ \\
Gl (0-3) & $0.4 \pm 0.5$ & $0.5 \pm 0.5$ & $0.3 \pm 0.4$ & $0.3 \pm 0.3$ & $0.3 \pm 0.4$ & $0.4 \pm 0.4$ & $0.3 \pm 0.4$ & $0.3 \pm 0.4$ \\
\hline
\end{tabular}

No examination period showed a significantly different score (Friedman test).

Table 3.

Changes in Gingival Height Before and After Surgery

\begin{tabular}{|c|c|c|c|c|c|c|c|c|}
\hline & \multirow[b]{2}{*}{ Baseline } & \multicolumn{7}{|c|}{ Month } \\
\hline & & I & 3 & 6 & 12 & 18 & 24 & 36 \\
\hline $\mathrm{GR}(\mathrm{mm})$ & $3.67 \pm 0.58$ & $0.88 \pm 0.42 *$ & $0.55 \pm 0.44 * t$ & $0.33 \pm 0.33 * \dagger$ & $0.29 \pm 0.37 * \dagger$ & $0.29 \pm 0.37^{*}+$ & $0.31 \pm 0.43 * \dagger$ & $0.33 \pm 0.43 * \dagger$ \\
\hline $\begin{array}{l}\text { GR reduction } \\
\text { from baseline }\end{array}$ & & $2.79 \pm 0.49$ & $3.12 \pm 0.52$ & $3.33 \pm 0.53$ & $3.38 \pm 0.52$ & $3.38 \pm 0.52$ & $3.36 \pm 0.57$ & $3.33 \pm 0.60$ \\
\hline $\begin{array}{l}\text { Root } \\
\text { coverage (\%) }\end{array}$ & & $76.31 \pm 10.45$ & $85.66 \pm 10.62$ & $91.25 \pm 8.43$ & $92.75 \pm 9.55$ & $92.75 \pm 9.55$ & $92.07 \pm 11.47$ & $91.28 \pm 11.47$ \\
\hline $\begin{array}{l}\text { Number of } \\
\text { completely } \\
\text { covered sites }\end{array}$ & & 2 & 5 & 9 & 12 & 12 & 12 & 11 \\
\hline $\begin{array}{l}\text { Creeping } \\
\text { attachment (mm) } \\
\text { from I month } \\
\text { after surgery }\end{array}$ & & & $0.33 \pm 0.29$ & $0.55 \pm 0.35 \ddagger \S$ & $0.60 \pm 0.44 \ddagger \S$ & $0.60 \pm 0.44 \ddagger \S$ & $0.57 \pm 0.5 । \ddagger \S$ & $0.55 \pm 0.52 \ddagger \S$ \\
\hline
\end{tabular}

* $P<0.01$ : Significantly different from baseline (repeated measures ANOVA).

$\dagger P<0.01$ : Significantly different from 1 month.

$\neq P<0.05$ : Significantly different from 3 months.

$\S P>0.05$ : No significant difference between any 2 values at $6,12,18,24$, and 36 months.

at 1 month compared to presurgery, and then continuously decreased up to 12 months. Even with slight rebound of GR and CAL after 12 months, the amounts were minimal and there were no statistically significant differences between the values of GR and CAL at any time interval after 12 months. WKG was also significantly increased at 1 month after surgery and then remained stable to 36 months.

Creeping attachment was first described by Goldman et al. ${ }^{34}$ as the "positive migration of the gingival margin in a coronal direction over a previously denuded root. This migration is often seen to continue for long periods postoperatively until a constant marginal level is reached." While the amount of creeping attachment is minimal (in general, $<1 \mathrm{~mm}$ ), the clinical importance can be significant because the presence of this factor adds to the predictability of a procedure. Harris ${ }^{21}$ reported that creeping attachment seems to occur commonly after connective tissue grafts. He selected the 4- week postoperative appointment as the creeping attachment starting point, based on his previous findings. In his study, 21 of 22 cases (95.5\%) showed creeping attachment, and the mean attachment obtained was $0.8 \mathrm{~mm}$ over an 8 -week period. In the present study, $0.55 \mathrm{~mm}$ of creeping attachment was observed at 36 months after surgery and had occurred in 16 of 22 sites $(72.7 \%)$ when compared to 1 -month postsurgery. The literature is limited as to when and if creeping attachment ever stops, how it progresses, and the ideal point to evaluate it. The recommendation that 1 year is the ideal period for evaluation is based on studies involving free gingival grafts. ${ }^{6,7}$ In the present study, creeping attachment is highest at 12 months after grafting. After 18 months, the amount of creeping attachment tended to decrease slightly, but there was no significant difference for any time interval from 6 to 36 months. Harris ${ }^{21}$ suggests that 6 to 9 months rather than 1 year is more likely when a connective tissue 
Table 4.

\section{Clinical Attachment Loss (CAL) Before and After Surgery}

\begin{tabular}{|c|c|c|c|c|c|c|c|c|}
\hline & \multirow[b]{2}{*}{ Baseline } & \multicolumn{7}{|c|}{ Month } \\
\hline & & I & 3 & 6 & 12 & 18 & 24 & 36 \\
\hline CAL (mm) & $5.26 \pm 0.77$ & $2.43 \pm 0.5 I^{*}$ & $2.31 \pm 0.54 *$ & $2.10 \pm 0.62 *$ & $2.00 \pm 0.57 *$ & $2.00 \pm 0.57 *$ & $2.10 \pm 0.58^{*}$ & $2.14 \pm 0.57 *$ \\
\hline $\begin{array}{l}\text { Attachment } \\
\text { gain }\end{array}$ & & $2.83 \pm 0.73$ & $2.95 \pm 0.81$ & $3.17 \pm 0.99$ & $3.26 \pm 1.04$ & $3.26 \pm 1.01$ & $3.17 \pm 1.05$ & $3.12 \pm 1.04$ \\
\hline
\end{tabular}

${ }^{*} P<0.01$ : Significantly different from baseline (repeated measures ANOVA).

Table 5.

Width of Keratinized Gingiva (WKG) Before and After Surgery

\begin{tabular}{lcccccccc}
\hline & & \multicolumn{5}{c}{ Month } \\
\cline { 3 - 8 } & Baseline & 1 & 3 & 6 & 12 & 18 & 24 & 36 \\
\hline WKG $(\mathrm{mm})$ & $0.88 \pm 0.72$ & $2.81 \pm 0.49 *$ & $2.88 \pm 0.50 *$ & $2.90 \pm 0.52 *$ & $2.90 \pm 0.54 *$ & $2.86 \pm 0.53 *$ & $2.86 \pm 0.50 *$ & $2.83 \pm 0.58 *$ \\
$\begin{array}{l}\text { Increase of } \\
\text { WKG }\end{array}$ & & $1.93 \pm 0.78$ & $2.00 \pm 0.74$ & $2.02 \pm 0.81$ & $2.02 \pm 0.77$ & $1.98 \pm 0.80$ & $1.98 \pm 0.75$ & $1.95 \pm 0.85$ \\
\hline
\end{tabular}

* $P<0.01$ : Significantly different from baseline (repeated measures ANOVA).

with pedicle flap is used, because there are no significant changes between the amounts of creeping attachment seen at any time interval after 26 to 38 weeks in his studies. Further studies may provide more detailed information in this area.

In this study, no conditioning agent was employed in root surface treatment during surgery. Many investigators have utilized citric acid ${ }^{9,15,16}$ or tetracycline ${ }^{16,19-24}$ solutions in root surface biomodification, in the belief that removing smear layer and exposing collagen fibrils would aid in better reattachment of grafted tissue. However, Bouchard et al. ${ }^{15}$ failed to show the benefit of citric acid conditioning in root coverage with subepithelial connective tissue grafts. In another report, ${ }^{16}$ they failed to demonstrate a difference between tetracycline and citric acid conditioning in root coverage therapy. At present, there is insufficient human biopsy material or histologic evidence available to determine the quality of wound healing following root conditioning with tetracycline or citric acid.

The ultimate goal in periodontal therapy is regeneration. Thus, the ideal objective is the establishment of a new connective tissue attachment with fibers inserting into new bone and new cementum on a previously diseased root surface. However, animal ${ }^{35}$ and human ${ }^{36}$ histologic evaluations revealed that true regeneration was not seen in root coverage obtained with a connective tissue graft. Biopsy studies ${ }^{35,36}$ indicated that the attachment of the graft to the root surface appeared to be mediated by a combination of epithelial downgrowth and connective tissue attachment, and that there is little potential for new cementum and new bone formation. However, despite the histologic findings, the connective tissue graft is still an effective method to obtain root coverage. The results seen are adequate by clinical parameters and seem stable over a 3-year period, as demonstrated in this study.

In conclusion, the connective tissue graft with a partial-thickness coronal advancement pedicle is a predictable method for root coverage and, provided that optimal maintenance care is provided, the clinical outcomes gained by this technique can be well maintained over a 3-year period.

\section{ACKNOWLEDGMENTS}

The authors thank Drs. Tae-Il Kim and Seung-Yoon Shin for their help in preparing the manuscript. This study was supported by Seoul National University Hospital grant 420000620, Seoul, Korea.

\section{REFERENCES}

1. Goldstein M, Brayer L, Schwartz Z. A critical evaluation of methods for root coverage. Crit Rev Oral Biol 1996;7: 87-89.

2. Caffesse RG, Alspach SR, Morrison EC, Burgett FG. Lateral sliding flaps with and without citric acid. Int $J$ Periodontics Restorative Dent 1987;7(6):43-57.

3. Allen EP, Miller PD. Coronal positioning of existing shallow marginal tissue recession. J Periodontol 1989;60: 316-319.

4. Romanos G, Bernimoulin JP, Marggraf E. The double 
lateral bridging flap for coverage of denuded root surface: Longitudinal study and clinical evaluation after 5 to 8 years. J Periodontol 1993;64:683-688.

5. Trombelli L, Scabbia A, Wikesjö UM, Calura G. Fibrin glue application in conjunction with tetracycline root conditioning and coronally positioned flap in the treatment of human gingival recession defects. J Clin Periodontol 1996;23:861-867.

6. Borghetti A, Gardella JP. Thick gingival autograft for the coverage of gingival recession: A clinical evaluation. Int J Periodontics Restorative Dent 1990;10:217-229.

7. Matter J. Creeping attachment of free gingival grafts: A five year follow-up study. J Periodontol 1980;51:681685.

8. Laney JB, Saunders VG, Garnick JJ. A comparison of two techniques for attaining root coverage. J Periodontol 1992;63:19-23.

9. Jahnke PV, Sandifer JB, Gher ME, Gray JL, Richardson AC. Thick free gingival and connective tissue autografts for root coverage. J Periodontol 1993;64:315-322.

10. Paolantonio M, di Murro C, Cattabriga A, Cattabriga M. Subpedicle connective tissue graft versus free gingival graft in the coverage of exposed root surfaces. A 5-year clinical study. J Clin Periodontol 1997;24:51-56.

11. Raetzke PB. Covering localized areas of root exposure employing the "envelope" technique. J Periodontol 1985;56:397-402.

12. Langer B, Langer L. Subepithelial connective tissue graft technique for root coverage. J Periodontol 1985;56: 715-720.

13. Nelson SW. The subpedicle connective tissue graft. A bilaminar reconstructive procedure for coverage of denuded root surfaces. J Periodontol 1987;58:95-102.

14. Borghetti A, Louise F. Controlled clinical evaluation of the subpedicle connective tissue graft for the coverage of gingival recession. J Periodontol 1994;65:1107-1112.

15. Bouchard P, Etienne D, Ouhayoun JP, Nilveus R. Subepithelial connective tissue grafts in the treatment of gingival recessions. A comparative study of 2 procedures. $J$ Periodontol 1994;65:929-936.

16. Bouchard P, Nilveus R, Etienne D. Clinical evaluation of tetracycline $\mathrm{HCl}$ conditioning in the treatment of gingival recession. A comparative study. J Periodontol 1997; 68:262-269.

17. Allen AL. Use of the supraperiosteal envelope in soft tissue grafting for root coverage. I. Rationale and technique. Int J Periodontics Restorative Dent 1994;14:216227.

18. Allen AL. Use of the supraperiosteal envelope in soft tissue grafting for root coverage. II. Clinical results. Int $J$ Periodontics Restorative Dent 1994;14:302-315.

19. Harris RJ. The connective tissue and partial thickness double pedicle graft: A predictable method of obtaining root coverage. J Periodontol 1992;63:477-486.

20. Harris RJ. The connective tissue with partial thickness double pedicle graft: The results of 100 consecutively treated defects. J Periodontol 1994;65:448-461.

21. Harris RJ. Creeping attachment associated with the connective tissue graft with partial-thickness double pedicle graft. J Periodontol 1997;68:890-899.

22. Müller HP, Eger T, Schorb A. Gingival dimensions after root coverage with free connective tissue grafts. J Clin Periodontol 1998;25:424-430.

23. Harris RJ. A comparative study of root coverage obtained with guided tissue regeneration utilizing a bioabsorbable membrane versus the connective tissue with partial-thickness double pedicle graft. J Periodontol 1997; 68:779-790.

24. Jepsen K, Heinz B, Halben J, Jepsen S. Treatment of gingival recession with titanium reinforced membranes versus connective tissue grafts. J Periodontol 1998;69: 383-391.

25. Tinti C, Vincenzi G, Cortellini P, Pini Prato G, Clauser C. Guided tissue regeneration in the treatment of human facial recession. A 12-case report. J Periodontol 1992; 63:554-560.

26. Roccuzzo M, Lungo M, Corrente G, Gandolfo S. Comparative study of a bioresorbable and a non-resorbable membrane in the treatment of human buccal gingival recessions. J Periodontol 1996;67:7-14.

27. Rachlin G, Koubi G, Dejou J, Franquin JC. The use of a resorbable membrane in mucogingival surgery. Case series. J Periodontol 1996;67:621-626.

28. Shieh AT, Wang HL, O'Neal R, Glickman GN, MacNeil RL. Development and clinical evaluation of a root coverage procedure using a collagen barrier membrane. $J$ Periodontol 1997;68:770-778.

29. Hancock E.B. Regeneration procedures. In: Proceedings of the World Workshop in Periodontics. Chicago: The American Academy of Periodontology; 1989;VII-1-VII-21.

30. de Waal $\mathrm{H}$, Kon S, Ruben $M$. The laterally positioned flap. Dent Clin North Am 1988;32:267-286.

31. Silness J, Löe H. Periodontal disease in pregnancy. II. Correlation between oral hygiene and periodontal condition. Acta Odontol Scand 1964;21:121-135.

32. Löe H, Silness J. Periodontal disease in pregnancy. I. Prevalence and severity. Acta Odontol Scand 1963;22: 533-551.

33. Miller PD. A classification of marginal tissue recession. Int J Periodontics Restorative Dent 1985;5(2):8-13.

34. Goldman H, Schluger S, Fox L, Cohen DW. Periodontal Therapy, 3rd ed. St. Louis: C.V. Mosby Co.; 1964:560.

35. Guiha R, Khodeiry SE, Mota L, Caffesse R. Histologic evaluation and healing and revascularization of the subepithelial connective tissue graft. J Periodontol 2001; 72:470-478.

36. Harris RJ. Human histologic evaluation of root coverage obtained with a connective tissue with partial thickness double pedicle graft. A case report. J Periodontol 1999; 70:813-821.

Correspondence: Dr. Chong-Pyoung Chung, Department of Periodontology, College of Dentistry, Seoul National University, 28 Yongon-Dong, Chongno-Ku, Seoul 110-749, Korea. Fax: 82-2-744-0051; e-mail: ccpperio@snu.ac.kr.

Accepted for publication May 17, 2002. 